\title{
Idrott, arenor och politik
}

\section{Anmälning av Johnny Wøllekær: Tidens krav er sportens krav. Studier i den kommunale idrætspolitikdannelse i Odense, Århus og Ålborg 1900-1950. Syddansk universitet, 2007, 273 s.}

\section{Av Jan Lindroth}

Den idrottshistoriska forskningen i Norden har mestadels varit upptagen av rikshistoriska perspektiv. Både lokalplanet och den internationellt övergripande tematiken har fått mindre uppmärksamhet. Tendensen är inte onaturlig, allra minst när det gäller en företeelse som har så mycket gemensamt med nationellt tänkande och organisering på nationell nivå. Inte desto mindre står det klart att i varje fall den frivilligt organiserade idrotten började med föreningar på lokalplanet. Lika uppenbart är att verksamhetens stora massa ägt rum just där och att den nationella historien underbyggs underifrån i ett spännande samspel. Det är därför ytterst angeläget att idrottslivets lokala utveckling uppmärksammas av forskningen.

Fortfarande sett $\mathrm{i}$ ett nordiskt perspektiv har det lokalhistoriska perspektivet i viss mån beaktats tidigare. Begränsar man sig till doktorsavhandlingar kan Bode Janzons redan 1978 ventilerade avhandling om Göteborgs idrottsliga föreningsliv ses som pionjärstudien (dock i kombination med hälsoperspektiv på nationell nivå). Matti Goksöyrs avhandling om Bergen (1991) och Leif Yttergrens om Stockholm (1996) följer samma väg: idrottens (i synnerhet föreningarnas) utveckling $\mathrm{i}$ en stor stad fram till sekelskiftet 1900. En fjärde avhandling, Morten Mortensens (2004), varierar det lokalhistoriska temat högst avsevärt genom att huvudsakligen studera 1900-talet och dessutom fokusera tre olikartade samhällen (Köpenhamn, Ballerup och Skive). Ett likartat grepp tog Paul Sjöblom (2006) genom att dels välja ut likaledes tre olikartade samhällen (en relativt liten svensk stad, Norrtälje, och två ännu mindre orter), dels omfatta större delen av 1900-talet.

Johnny Wöllekær är alltså i gott historiografiskt sällskap när han sommaren 2007 vid Syddansk universitet lade fram sin PhDavhandling. Denna sjätte men förhoppningsvis långtifrån sista lokalhistoriska idrottsavhandling både ansluter sig till föregångarna och bryter ny mark. Den avser tre orter (samhällen) perioden 1900-1950, vilket känns igen. Originellt är att dessa orter, som framgår av undertiteln, gäller Danmarks tre största provinsstäder under storebror Köpenhamn. Med detta val är det likheten som eftersträvats i fråga om empiriskt underlag, vilket ökar möjligheterna till generalisering men minskar kontrasterna. Även tyngdpunkterna har lagts något annorlunda: större tyngdpunkt på den kommunala politiken och idrottsplatserna, min- 
dre på det allmänna idrotts- och föreningslivet. Tillspetsat är det fråga om idrottsplatshistoria, om när, hur och varför möten utspelar sig mellan idrottens föreningar och kommunala instanser med visst utrymme också för näringsliv och opinionsbildare. Kommunal idrottsplatspolitik är kanske den mest träffande karakteristiken i kortform.

Avhandlingen sönderfaller i två delar. Den första (kapitlen 1-7) redogör för utgångspunkter och tecknar bakgrunden i skilda avseenden. Dessutom redovisas perspektiv på den nationella nivån av självständigt värde - något av en bonus. Den andra består av de tre lokala punktstudierna samt sammanfattning, diskussion och perspektivering huvudsakligen baserade på dessa studier (8-12). Tre grundläggande problemområden (frågeställningar) anger JW på tidigt stadium: 1) Hur blev idrotten institutionaliserad i kommunerna, 2) hur behandlades den $\mathrm{i}$ de tre kommunerna (inklusive komparation) och 3) vilken argumentering och vilka bakomliggande krafter gjorde sig gällande i samband med idrottens anläggningsfrågor? Samtliga är rimliga, den sista mest nyanserad och i praktiken avgörande. Avhandlingen har också förtjänsten av att vägledas av en »gennemgående tese $\ll$, nämligen att man på kommunal nivå föregrep den nationella utvecklingen inklusive offentligt stöd till idrotten; tanken på idrott som led i den offentliga välfärdspolitiken grundlades snarare i de tre undersökta städerna än i de rikspolitiska representantskapen i Köpenhamn (en tes vars prövning dock försvåras av att den idrottsliga rikspolitiken är anmärkningsvärt lite undersökt).

I sedvanligt utförlig form redogörs för teoretiska utgångspunkter och begreppsapparat. Centrala begrepp blir »idraetspolitikdannelse« (den process varigenom idrotten dras in i den kommunala beslutssfären), kommunaliseringsprocessen (graden av kommunal involvering inklusive förskjutningar i denna) och beslutsprocessanalys. Ytterligare inslag i begreppsapparat och teoretisk grund återfinns i några figurer. De motiverar omdömet att denna sida av arbetet är väl tillgodosett, med snudd på överambition. Man gör nämligen reflexionen att bara delar av begreppsapparat och figurer blir konsekvent använda och värdefulla verktyg genom avhandlingen. Störst betydelse har indelningen i idealtypiska relationer mellan kommunerna och idrottsanläggningarna (figur 2.2), där fyra alternativ presenteras: komplett kommunalisering (kommunen tar hand om helheten), aktiv kommunalisering, passiv kommunalisering, negativ kommunalisering (kommunen avstår helt från pekuniärt stöd). När det kommer till kritan är avhandlingen, trots de ambitiösa och insiktsfulla preludierna, i huvudsak att se som en välgjord deskriptiv och empirisk framställning, detta sagt som karakteristik mer än som kritik.

JW har en mycket god hand med den kommunala sidan, med de olika instanser och personer som den representerades av och ärendenas gång genom papperskvarnen. Även det kommunala källmaterialet erbjuder mer glädjeämnen än problem. Detta bidrar till avhandlingens kommunalpolitiska karaktär. På idrottssidan tilltar svårigheterna. Det beror delvis på källmaterialet. De strategiska och taktiska överväganden som måste ha förekommit bland idrottens föreningsledare tycks inte gärna ha fästs på papper, exempelvis i protokoll eller korrespondens. Till skillnad från den offentliga sektorn kan inte den privata avkrävas genomskinlighet och offentlighetsprincip. Inte desto mindre förvånar det att 
så litet av föreningsarkiv är indragna i undersökningen.

Det föreligger även en annan svårighet eller i varje fall otydlighet på idrottssidan: hur definieras och selekteras den idrott som ska beaktas i studien? I praktiken blir det främst de centrala arenaidrotterna med grenar som fotboll, friidrott och lite till som fokuseras. Det aktualiserar den klassiska idrottsarenan, vad jag i en svensk idrottsplatsstudie kallat »rektangeln i ovalen«. Att förse sin stad med en större, modern arena av detta slag blir huvudfrågan, som JW följer konsekvent och utförligt. Som mindre självklar framstår den stora plats badanläggningarna tilldelas. Man kan undra om hygieniskt grundad badverksamhet över huvud taget är idrott (den fysiska aktiviteten kan ju inskränka sig till bruk av tvål tillsammans med vattenbegjutning). Inte heller blir man övertygad om att en idrottslig föreningsverksamhet ligger bakom dessa anläggningar och denna verksamhet.

Det som faller utanför dessa anläggningar framstår som mera tillfälligt. Här passerar anläggningar för en rad skilda idrotter revy med början i tidig, intressant cricketkultur, via cykelbanor, tennisbanor och badmintonhallar. I förebigående noterar man ett större anslag till en golfbana som Ålborg på socialdemokratiskt initiativ beviljade. I slutändan avtecknar sig den moderna inomhushallen. Man frågar sig om inte hästsporten och seglingsporten hade sina anläggningsbehov som drogs in i kommunpolitiken. De faller bättre än bad- och simverksamheten in i idrottsbegreppet.

JW kan ha goda skäl för sin inringning av den idrottsverksamhet han studerat. Kanske har han helt enkelt valt ut det som faktiskt behandlats enligt det kommunala källmaterial han följt. Som vägledning har han redan i sin första not markerat att »be- tegnelsen idræt anvendes i afhandlingen som en fællesbetegnelse for fysiske aktiviteter i bred forstand, hvorimod gymnastik og sport i denne undersögelse bruges som dækkende mere specifikke konstruktioner.» Något längre fram (s. 8) redovisas gränsdragningar som innebär att skolidrotten och den oorganiserade idrotten bara ingår där den har relevans för det centrala undersökningsobjektet, nämligen föreningsidrotten (idrætsbevegelsen). Hanteringen av denna urvalsproblematik kunde emellertid ha klargjorts med större tydlighet inklusive konsekvenserna av träffade val. Exempelvis framskymtar skolans roll i fråga om idrottsanläggningar på många håll utan att riktigt komma till sin rätt. Samtidigt måste erkännas att det är ett stort och snårigt fält vi har att göra med.

Som huvudresultat framträder det likformiga samspelet mellan hög industrialiseringsgrad, demografisk och bebyggelsemässig expansion, socialdemokratisk ledning och benägenheten att satsa kommunala medel och kommunalt inflytande på moderna idrottsanläggningar med början senast under mellankrigstiden. Det positiva sambandet mellan industrialisering och föreningsledd tävlingsidrott får här sin bekräftelse i den meningen att avancerade kommuner visade sig vilja satsa på moderna idrottsanläggningar. Vidare beläggs slutsatsen att idrottsrörelsen en bit in på 1900-talet blivit en allt starkare maktfaktor att räkna med vid sidan av kommunens alla andra intressenter. Väl framhävt är även sambandet mellan socialdemokratisk hegemoni och en positiv inställning till kommunal involvering i idrottsplatser. Detta senare samband illustreras av den större tröghet som den centrala idrottsplatsfrågan behandlades med i det länge konservativt styrda Odense, jämfört med de tidigare socialdemokratiskt 
styrda Århus och Ålborg. Men samtidigt kunde socialdemokratin i Århus tidvis samarbeta inte bara med näringslivet utan även med politiskt konservativa krafter till förmån för en tidsenlig idrottspark.

Frågan blir därför om inte detta samband mellan politisk huvudinriktning och benägenhet för kommunal idrottsinvolvering ses alltför endimensionellt. Nyanseringar hade kunnat berika bilden. Var stöd till idrottsanläggningar bara utslag av en positiv inställning till tävlingsidrotten? Inte nödvändigtvis. Det kan exempelvis också ha handlat om att få kontroll över en verksamhet som visade både goda och mindre goda sidor. Ett sådant kontrollmotiv, måhända byggt på tvivel på fria krafters spel, kan ha gjort sig gällande utan att sättas på pränt. Det är också angeläget att framhålla skillnaden mellan en positiv inställning till idrotten och till att ge den kommunalt stöd. I princip kunde (och kan) man vara en glödande idrottsvän men lika glödande motståndare till kommunal finansiering. Det är därför inte självklart att den konservativa majoriteten i Odenses beslutande organ var negativ till idrotten i sig. Att visa det fordrar en annan studie, som i och för sig kan leda till samma slutsats. Här handlar det även om synen på gränserna för kommunens åtaganden. Lite förvånande är slutligen att det positiva sambandet mellan borgerlighet och tävlingsidrott, parallellt med socialistiska tvivel, under pionjärdecennierna inte framträder mera. Självfallet är JW medveten om synpunkter av detta slag. Min invändning är att de gärna kunde ha diskuterats mera.

Avhandlingen är försedd med omfattande summerande delar (kapitel 11-12). I någon mån förefaller de att överlappa varandra - men hellre det än att vara alltför summariska. Det finns många exempel på avhandlingar som är alltför snåla när det gäller att vrida och vända på de med mycket möda framtagna resultaten. Till det man fäster sig vid hör den konstruktiva indelningen av de idrottspolitiska argumenten, i tabellform presenterade under rubriken $»$ de politiske artikulationsfelter« (11.1). Fyra sådana urskiljs genom nyckelorden socialpolitik, sundhetspolitik, sysselsättningspolitik och modernitet. De talar egentligen för sig själva och skapar god ordning i summeringarna. Det första fältet avser, som väntat, socialpreventiva effekter i första hand riktade till ungdomen. Även sundhetsfältet kan betraktas som primärt baserat $i$ ett preventivt tänkande. Påfallande är, vilket JW påpekar, att alla tre städerna använde sig av argument inom detta fält utan att hänvisa till vetenskaplig dokumentation. $\AA$ andra sidan måste man då överväga vilken dokumentation som faktiskt förelåg. I varje fall i Sverige kunde en framstående läkare i den danske fysiologen Johannes Lindhards anda kring 1930 ifrågasätta om kroppsövningar över huvud taget var nyttiga.

Den tredje argumenttypen leder in på ett tidsbegränsat förhållande: arbetslösheten. Mellan krigen beslöts på politisk nivå att arbetstillfällen skulle skapas för att minska den sjunkande sysselsättningen och det visade sig att byggandet av idrottsanläggningar hade fördelar som projekt. Man kan tala om en positiv faktor som kom de idrottsplatsivrande kretsarna gratis till del. Mer svårfångad och spännande är den sista argumenttypen: moderniteten. Här visas att det växte fram en uppfattning även utanför idrottsrörelsen innebärande att en stor och tidsenlig idrottsanläggning var något som en större stad absolut borde hålla sig med för att inte förlora sin självaktning. Den framstod som ett led i stadens allmänna frammarsch och strävan att följa med sin tid. 
I detta sammanhang noteras i förbigående att en sådan anläggning »passede perfekt ind i kommunalpolitikernes önske om at tiltræke sig opmærksomhed«. Det leder vidare till frågan om inte tävlingsidrottsliga framgångar skulle väcka ännu större uppmärksamhet, varvid den goda arenan bara utgjorde en förutsättning. Det tycks inte som om sådana tankar och argument spelade nämnvärd roll under första hälften av 1900talet. Betyder det att de inte alls förekom? Utan tvivel har de haft sin betydelse därefter. En annan sak är att kommunalpampar av skilda slag även senare dröjde med att öppet erkänna sådana drivkrafter. Men att de funnits och alltmer finns kan inte bestridas i en tid då stora idrottsliga (skryt)byggen och politiker som låter sig bestrålas av idrottsstjärnor blivit vanliga och accepteras i breda kretsar. Kanske har Odenses konservativa politiker anledning att vända sig $\mathrm{i}$ sina gravar!
JW:s avhandling ger ett värdefullt bidrag till den urbanhistoriska idrottsforskningen, i vidare mening till den idrottens lokalhistoria som har så mycket intressant att bjuda. Den formella akribin är god men inte på allra högsta nivå. En lite skarpare samlad precisering av uppläggning och resultat i förhållande till föregångarnas hade varit önskvärd, så mycket mer som dessa (med god nordisk täckning) är föredömligt inlästa och beaktade. Utgångspunkterna klarläggs mycket ambitiöst. Ett huvudresultat framgår med all önskvärd tydlighet som toppen på en pyramid av goda delresultat. Samtidigt försvåras tesen om den lokala utvecklingens primat framför den nationella av det faktum att motsvarande kunskap inte föreligger på den senare nivån. Förhoppningsvis fylls luckan ut inom rimlig tid, varför inte med JW själv i spetsen! 
